\title{
PROBLEMEN, VEBONDEN AAN EEN SNELLE VERSLAGLEGGING DOOR ONDERNEMINGEN
}

\author{
door I. M. Hage
}

Snelle verslaglegging is een betrekkelijk begrip.

Men kan er onder verstaan een verslaglegging, die plaats vindt zodra dit na de afloop van enig boekjaar mogelijk is; een verslaglegging dus, die niet om opportunistische redenen wordt verschoven naar een aan de onderneming en/of haar leiding beter passend, later tijdstip.

Men kan er ook onder begrijpen een verslaglegging, die opvallend snel na de afloop van een boekjaar, dus b.v. binnen 2 a 3 weken in de openbaarheid treedt; een zo snelle verslaglegging, dat zelfs de deskundige buitenstaander zijn bewondering en ook wel zijn verwondering uitspreekt over het tempo en zich afvraagt, hoe het mogelijk is, dat de betrokken onderneming het klaar speelt binnen een zo kort tijdsverloop met een, toch aan redelijke eisen beantwoordend, verslag voor de dag te komen.

In beide gevallen kan men zich voorstellen, dat er zich problemen kunnen voordoen, welke eerst tot oplossing moeten worden gebracht, alvorens tot openbare verslaglegging $\mathrm{kan}$ worden overgegaan. In het tweede geval doet zich echter daarenboven nog een probleem van bijzondere aard voor, nl. op welke wijze binnen de beschikbare, korte spanne tijds de vereiste zekerheid kan worden verkregen, dat de verslaglegging inderdaad aan redelijke maatstaven voldoet.

De problemen van de laatste categorie zullen in het navolgende nader worden bezien. Daarbij zal worden getracht zowel het ondernemingsaspect als het aspect voor de controlerende accountant van de aan snelle verslaglegging verbonden problematiek te belichten.

Indien wordt afgezien van de overwegingen, die tot een snelle verslaglegging nopen, of althans deze wenselijk doen zijn, - deze zijn op zichzelf beschouwd misschien wel interessant, maar hier niet ter zake dienende vormt de snelle verslaglegging voor de leiding van een onderneming een probleem van in hoofdzaak administratief-organisatorische en slechts ten dele van administratief-technische aard.

Wat de problemen van administratief-organisatorische aard betreft, is het niet voldoende te stellen, dat de administratieve organisatie aan redelijke eisen moet beantwoorden. De inrichting van de administratie dient zodanig te zijn, dat zij een snelle verslaglegging in een rustige, normale sfeer mogelijk maakt. Noch in de maand die aan de afloop van het boekjaar voorafgaat, noch in de korte periode die ligt tussen de afloop van het boekjaar en de verslaglegging mag er van een opeenhoping van werkzaamheden en/of van een extra versnelling van het tempo der werkzaamheden sprake $z$ ijn.

In de praktijk betekent dit, dat de administratieve organisatie niet alleen in de 6 à 8 weken, die aan de verslaglegging voorafgaan, maar het gehele boekjaar door op een snelle en volkomen betrouwbare verantwoording ingesteld moet zijn. Een snelle en volkomen betrouwbare verantwoording in deze $z$ in is in principe slechts bereikbaar als de administratie zo is ingericht dat de dagelijkse verantwoordingen als volkomen betrouwbare basis kunnen dienen voor de opbouw van de wekelijkse verantwoordingen en deze op haar beurt weer voor vier-wekelijkse of maandelijkse recapitulaties en de daaruit samen te stellen balansen, resultatenrekeningen, overzichten en verslagen. 
Van de vierwekelijkse of maandelijkse stukken naar de kwartaalbalansen, resultatenrekeningen, overzichten en verslagen, dus ook naar de stukken, die het gehele boekjaar omvatten, il n'y a qu'un pas.

Het belangrijkste probleem waarvoor de leiding van de administratie dus bij voortduring wordt gesteld, is de regulering van de stroom van de te verwerken gegevens op zodanige wijze, dat deze logisch in het verband van de dagverantwoording passen.

Zonder nader betoog is het wel duidelijk, dat dit geen eenvoudig probleem is en dat het slechts oplosbaar is als de aard van de onderneming geen onoverkomelijke moeilijkheden opwerpt. Maar gesteld, dat er geen onoverkomelijke moeilijkheden zijn, dan nog zullen van geval tot geval de omstandigheden kunnen verschillen en kan zelfs de vraag rijzen of de technisch mogelijke oplossing in economisch opzicht wel verantwoord is.

Te dien aanzien moet o.m. worden gedacht aan de schoksgewijze toevloed van de te verwerken gegevens, aan productieprocessen, die een aantal dagen, weken of zelfs maanden vergen. Men oordele echter niet lichtvaardig, want als de schokken met een regelmatige frequentie voorkomen, de ",langdurige" productieprocessen regelmatig, in dagelijks, wekelijks of althans periodiek aanvangende series naast elkander lopen, bestaat er, principiëel gezien, geen of slechts een klein verschil met de eenvoudiger liggende gevallen.

Als hiervoren werd gesproken van de noodzakelijkheid van dagelijkse verantwoordingen, die als volkomen betrouwbare basis voor de verdere opbouw moeten dienen, dan dient hieraan nog de eis te worden toegevoegd, dat deze dagelijkse verantwoordingen, op de dag waarop zij betrekking hebben of uiterlijk op de volgende werkdag gereed moeten zijn. Evenzo dient aan de samenstelling van de stukken, die een langere periode omvatten, slechts een paar dagen te worden besteed.

Voorts ligt hierin opgesloten, dat alle gegevens, die in de jaarlijkse verslaglegging tot uitdrukking worden gebracht, in beginsel in de systematiek van de dagelijkse verantwoording moeten kunnen worden teruggevonden.

De hiermede verbonden problemen zijn uiteraard van technische aard.

Opdat de snelheidseisen geen afbreuk zullen doen aan de eis van volkomen betrouwbaarheid is intussen toch in het algemeen wel het volgen van een bijzondere techniek gewenst, zo niet noodzakelijk, nl. dat de controle zowel op de individuele gegevens als op de totaliteit dier gegevens zoveel mogelijk naar het begin der werkzaamheden wordt verlegd.

Deze controle moet dan zo worden georganiseerd, dat in beginsel elke employé na het uitvoeren van een bepaalde taak op een eenvoudige wijze zelf kan vaststellen, dat hij deze taak inderdaad zonder fout heeft volbracht. Het interne controleorgaan kan bij deze organisatie volstaan met een zeer snelverlopende nacontrole, waarna onmiddellijk met de verdere verwerking in samenvattende overzichten en recapitulaties kan worden begonnen.

De achtereenvolgende wekelijkse-, 4-wekelijkse- of maandelijkse- en kwartaalgegevens moeten steeds weer worden vergeleken en de afwijkingen worden verklaard.

Al naar de gegevens zich daartoe lenen, krijgt de leiding der onderneming aldus dagelijks, wekelijks, 4-wekelijks of maandelijks de beschikking over de gegevens, die zij voor haar openbare verslaglegging behoeft.

In theorie kan zij bij de beschreven organisatie op elk gewenst, willekeu- 
rig moment op een niet van de snelheid van de jaarlijkse verslaglegging afwijkend tempo tot een overeenkomstige verslaglegging overgaan.

In de praktijk wordt zij korte tijd na afloop van elke 4-wekelijkse of maandelijkse periode met het balansbeeld in optima forma geconfronteerd. Verrassingen kan dit beeld niet bieden, daar zij van de mutaties in de voornaamste vermogensbestanddelen doorlopend op de hoogte is.

De resultatenrekening kan evenmin onverwachte aspecten vertonen, daar de leiding van dag tot dag op de hoogte kan zijn van de gang van zaken. Past men daarenboven nog als vergelijkingsmateriaal het systeem van "glijdende" jaarcijfers ${ }^{1}$ ) toe, dan is het gevaar van een formeel of materieel "vertekend" beeld in technisch opzicht vrijwel uitgesloten.

Een parallel lopend budgetteringssysteem kan ten deze uiteraard eveneens uitnemende diensten bewijzen.

Als de technische problemen aldus zijn opgelost, staat er ogenschijnlijk aan een snelle verslaglegging niets meer in de weg.

Met de oplossing van de technische problemen is men er echter nog niet.

Ook bij de consequente toepassing van een algemeen als redelijk aanvaard stelsel van waardering der vermogensbestanddelen, waaronder ook de economische voorraden en de "long"- en "short"-posities in vreemde valuta's moeten worden gerekend, kan de nabije toekomst gevaren opleveren. die op het moment van de verslaglegging redelijkerwijze niet konden worden voorzien. De leiding ziet zich daarom telken jare voor het probleem geplaatst of en in hoeverre de technisch juiste jaarcijfers correctie behoeven door rekening te houden met de minima van nadelige risico's. Dit zijn dan de problemen van de afschrijvings-, reserverings- en winstverdelingspolitiek.

De aanwezigheid van grote open en/of stille reserves gevormd uit de jaar in jaar uit behaalde winsten kan het zoeken naar en het vinden van een oplossing misschien vergemakkelijken, maar zij schakelt de telkens weerkerende confrontatie met het probleem niet uit.

Gesteld echter, dat er voldoende te achten voorzieningen voor mogelijke risico's getroffen zijn of kunnen worden, dan blijft nog de vraag te beantwoorden of hiervan, respectievelijk van de aanwending van de gevormde reserves, mededeling moet worden gedaan.

Dit is geen werkelijk probleem: deze mededeling dient zonder terughouding te geschieden. Bij een snelle verslaglegging bestaat echter de mogelijkheid, dat de mededeling van de aanwending moet worden verschoven naar het eerstvolgende jaarverslag.

Voor de leiding der onderneming, die erin slaagt de voormelde problemen op bevredigende wijze op te lossen, blifft nog slechts één vraag over. nl. deze, of de publieke accountant, die met de controle op de jaarrekening belast is, in staat en ook bereid is zijn medewerking te verlenen aan de beoogde snelle verslaglegging, m.a.w. de juistheid van het uitgebrachte verslag met zijn handtekening te bekrachtigen.

Met deze vraag is dan meteen het aspect voor de controlerende accountant van de aan snelle verslaglegging verbonden problematiek aan de orde gesteld.

Ongetwijfeld zal de accountant bereid gevonden worden alle medewerking te geven, die hij binnen de grenzen van zijn publieke functie verantwoord acht. Evenzeer mag worden aangenomen, dat hij in incidentele ge-

1) Zie T. G. Rose: Higher Control in Management. 
vallen van zeer dringende aard, al het mogelijke zal doen om binnen de gestelde termijn zijn controle te completeren en op grond daarvan zijn goedkeurende verklaring af te geven.

Iets anders is, of de accountant opdrachten kan aanvaarden, waarin de verwachting wordt uitgesproken, dat hij het tempo van $z$ ijn controle-werkzaamheden en meer in het bijzonder het tijdstip, waarop hij zijn eindrapport over enig boekjaar zal uitbrengen, zal aanpassen aan het snelle tempo van de leiding der te controleren onderneming.

Indien er sprake zou zijn van een eis, zonder meer, zou de opdracht stellig moeten worden afgewezen. Voor enige problematiek zou te dien aanzien geen ruimte bestaan. Wel komen er problemen naar voren als het er om gaat de opdrachtgever niet in zijn verwachtingen teleur te stellen.

Gesteld, dat alle opdrachtgevers een overeenkomstige verwachting zouden uitspreken, dan zou hij bij de geringe spreiding, die de boekjaren ten aanzien van het kalenderjaar vertonen, voor het merendeel van zijn opdrachten voor de practische onuitvoerbaarheid worden gesteld.

$E_{r}$ is n.l. geen enkele organisatie van een accountantskantoor denkbaar, die op verantwoorde wijze de dan onvermijdelijke opeenhoping van werkzaamheden zou kunnen opvangen.

Hieruit volgt, dat de accountant slechts bij wijze van uitzondering aan de wensen van cliënten ter zake zal kunnen voldoen. Aan de eis, dat ook in die uitzonderingsgevallen de controle volkomen moet zijn, mag echter geen enkele concessie worden gedaan.

De problemen, waarvoor de accountant geplaatst wordt, zijn daarom voor hem, evenals voor de leiding van de onderneming, uitsluitend van organisatorische en technische en niet van principiële aard. Na zorgvuldige analyse zal blijken, dat $z i j$ in één vraag kunnen worden samengevat: „Hoe richt ik mijn controleprogramma zó in, dat aan de volkomenheid van mijn controle op geen enkele wijze afbreuk wordt gedaan?"

Vanzelfsprekend zal het antwoord. al naar de omstandigheden verschillen. verschillend kunnen zijn.

De keuze van de aan te wenden controlemiddelen biedt overigens geen probleem, dat zich alleen maar voordoet, indien voor de afsluiting van de controle slechts beperkte tijd beschikbaar is. $\mathrm{Bij}$ de opstellinq van elk controleproqramma zal de accountant moeten nagaan, welke middelen hem ten dienste staan om in de gegeven situatie op rationele wijze tot zijn doel te geraken.

Bij de opstellinq van een controleprogramma, dat resulteert in een afwerking van de jaarrekening binnen een paar weken na afloop van een boekiaar, is het probleem slechts in zoverre van bijzondere aard. dat de accountant. althans ten aanzien van bepaalde vermogensbestanddelen meer in zijn keuze wordt beperkt dan wanneer hij geen rekening met een enge tijdslimiet behoeft te houden.

Zo zal hii b.v. niet de traditionele afloopcontrole op vorderingen, voorraden, in - en verkoopcontracten, enz. kunnen toepassen en zal hij zich moeten afvragen, of hij deze wel kan missen.

In sommige gevallen zal het antwoord bevestigend, in andere gevallen cntkennend kunnen luiden.

Als de vorderingen bestaan op een groot aantal vaste afnemers, die week in week uit voor een ongeveer gelijk bedrag aan goederen afnemen en ook regelmatig hun schuld afdoen, als er voorts voor de achterblijvers een goed 
en snel werkend maandsysteem bestaat en de ervaring van jaren heeft geleerd, dat gemiddeld slechts een onbelangrijk of misschien te verwaarlozen percentage van het bedrag der vorderingen oninbaar blijkt te zijn, kan de afloopcontrole rustig achterwege blijven en, zonder wezenlijke vergroting van enig risico, worden vervangen door een nauwlettend volgen van de excepties gedurende de loop van het boekjaar.

Evenmin zal de behoefte bestaan aan een ruim te nemen termijn voor de vorming van een gefundeerd oordeel over de grootte en de waardering van de voorraden als sluitstuk van de controle van de goederenbeweging en de daarmede verbonden geldelijke mutaties, indien de mogelijkheid daartoe permanent aanwezig is.

Dit zal het geval zijn als de productie en de afzet van de onderneming in kwestie gedurende een aantal boekjaren volkomen gelijkmatig verlopen en de marge tussen de prijzen van grondstoffen en producten geen fluctuaties vertoont, die bij voortduring het beeld vertroebelen en het verkrijgen van voldoende inzicht en daardoor het opstellen van een verantwoorde prognose onmogelijk maken.

Als de accountant de voorraadpositie en het daarop aansluitende in- en verkoopbeleid doorlopend en nauwlettend volgt, zal hij zijn actie bij het einde van het boekjaar ook hier kunnen beperken tot enkele simpele, weinig tijd vereisende werkzaamheden.

Wat betreft de voorraadpositie, met inbegrip van de nog af te wikkelen in- en verkoopcontracten, zal hij zich kunnen bepalen tot het beantwoorden van de vraag of deze in samenstelling en kwantiteit, opvallende verschillen vertoont met de als normaal te kwalificeren positie gedurende de loop van het boekjaar. Met betrekking tot de waardering zal hij slechts moeten vaststellen, dat deze past in het normaliter gevolgde marge-beleid, geen nogniet-gerealiseerde winstbestanddelen omvat of geen met zekerheid te verwachten verliezen buiten rekening laat, respectievelijk dat ten aanzien van eventuele min - of plus-posities op redelijke wijze rekening is gehouden met daarin verscholen nadelige risico's.

Meer in het algemeen kan men zeggen, dat de uitschakeling van controlemogelijkheden, en dus van controlewerkzaamheden, na de afloop van een boekjaar, zal moeten leiden tot een verschuiving naar werkzaamheden gedurende de loop van het boekjaar.

De uit deze verschuiving voortspruitende problemen zijn voornamelijk van organisatorische aard.

In elk geval zal het controleprogramma zodanig moeten worden opgesteld, dat de administratie op de voet kan worden gevolgd en doorlopend en zonder phase-verschil een scherp toezicht op de perfecte werking van de interne controle kan worden uitgeoefend.

Alle dag-en weekoverzichten, alsmede alle andere periodieke verantwoordingen, welke voor het controle-oordeel van belang kunnen zijn, zullen vanzelfsprekend op passende wijze in het programma moeten worden betrokken.

Deze richtlijnen volgende, zal het mogelijk zijn, bij een onderneming met een administratieve organisatie als hiervoren beschreven, reeds korte tijd na het einde van de 12 e vierwekelijkse periode, respectievelijk van de $11 \mathrm{e}$ maand van het boekjaar een goed gefundeerd oordeel te vormen over de gang van zaken en de daardoor verkregen resultaten, respectievelijk over de mutaties in het vermogen en zijn samenstellende bestanddelen sedert de aanvang van het boekjaar.

m a b blz. 331 
Daar er nu nog slechts één vierwekelijkse periode of één maand gecontroleerd behoeft te worden, blijft er voldoende tijd over voor de eindcontrole en de samenstelling van het rapport.

Het zou buiten het bestek van dit artikel vallen, de velerlei variaties van mogelijkheden, welke zich al naar de soort of grootte van de betrokken onderneming voordoen, in den brede te beschouwen.

Een zodanige beschouwing zou trouwens geen wezenlijke nieuwe gezichtspunten opleveren. Hoogstens zou zij kunnen dienen ter verdere adstructie van het in dit artikel verwerkte standpunt, dat de snelle verslaglegging door ondernemingen de accountant wel voor organisatorische en technische vraagstukken kan plaatsen, doch dat deze voor hem geen problemen van principiële aard opwerpt. 